The ET column is where we ask people in the know - academics, broadcasters, educators, linguists, teachers and others connected with English worldwide - to write a column for the journal on issues of controversy, debate, work in the field, and matters of topical and immediate interest.

\section{Notes from East Asia}

In Hong Kong there is little of the economic gloom still prevalent in Europe and the USA. Universities, for example, are in a state of crisis in the UK, but are in a moment of expansion here, as undergraduate courses move from a three-year programme to four, and more teachers are being urgently recruited. Mainland China, and with it the Hong Kong economy, seems now to have brushed aside the worst of the global downturn, and is back on a trajectory of fast growth.

This is what I'm thinking about as I'm preparing for the second of two public lectures on The future of English in Hong Kong. My first lecture in November was relatively straightforward, looking at the changing global landscapes of English during the last decade or so. The next lecture is more challenging: examining the future place of English in Hong Kong as its economic and physical integration with mainland China deepens. Hong Kong is rapidly becoming trilingual, with Putonghua (or Mandarin as it is still more commonly known outside mainland China) establishing itself as the third language. Will it overtake English as the second language of Hong Kong? That is the question my next lecture will focus on.

The rise of China may be rebalancing the world, but it is counter-balanced, to some extent, by the parallel rise of India - destined to overtake China in the size of its population. The future of English in the world will be shaped in large measure by the complex play-off between these two new cultural, political and economic Asian poles. I had a reminder of the importance of India in November, when I acted as a judge in a national English debating competition in Chennai (still known in the world of airport codes as Madras). The event was organised jointly by the UK Institute of Ideas and the British Council and was held in one of India's most prestigious universities - Indian Institute of Technology, Madras. It was a remarkable event in many ways - and I see it was made the subject of a BBC 'From our own correspondent' report. Debating Matters transcended the usual school debate format, allowing the younger generation to address some of the big Indian issues of the day in the company of leaders from business and the Arts. As well as the competitive debates, there was a 'Question Time', modelled on the $\mathrm{BBC}$ radio and television programmes. One of my co-panellists was the author Chetan Bhagat - merchant banker-turne-novelist who is now the best-selling English-language writer in India, so successful that some of his books (including One Night@the Call Center) have been turned into films. Chetan Bhagat is no Salman Rushdie, but is almost certainly a more important figure as far as the development of the English language in India goes. Last year Time magazine listed him as one of the 100 most influential people in the world, joining other such artists as Ricky Jervais, Elton John, Banksy and Simon Cowell.

What is less widely appreciated, at least outside India, is ChetanBhagat's mission to help ordinary people, particularly in rural areas, to improve their English reading skills. His novels are the kind sold in supermarkets for just over one pound, and he takes great care to ensure the language is accessible. His sales figures demonstrate the growing audience for such English-language novels in India.

I was invited to a talk in Bastar, a backward area ten hours' drive from the nearest airport of Raipur.

I asked them 'who reads Chetan Bhagat in Bastar?' They said 'tribal kids, they use your books to learn English'. It shows you the hunger. For my recent book, we did a round of simplification editing, so that the book is more accessible to Indians. Of course, critics in India hate me for it. But that's what critics do anyway, and if I am getting a chance to aid transforming a young person's life, I am not going to pass up on that.

I last shared a platform with Chetan Bhagat at a conference in Delhi just over a year ago. One of his many memorable quips then was the best summary I've heard of what it is to be a middle class bilingual from north India today.

I always say Hindi is like the mother, English is like the wife, and you can love both. Just don't ask who you love more - ever.

The Debating Matters event in Chennai was not just a challenge for the sixth formers from around India whose debating skills had allowed them to reach the finals, but also for me. I had been invited by the British Council to speak as 'an expert witness' for the motion 


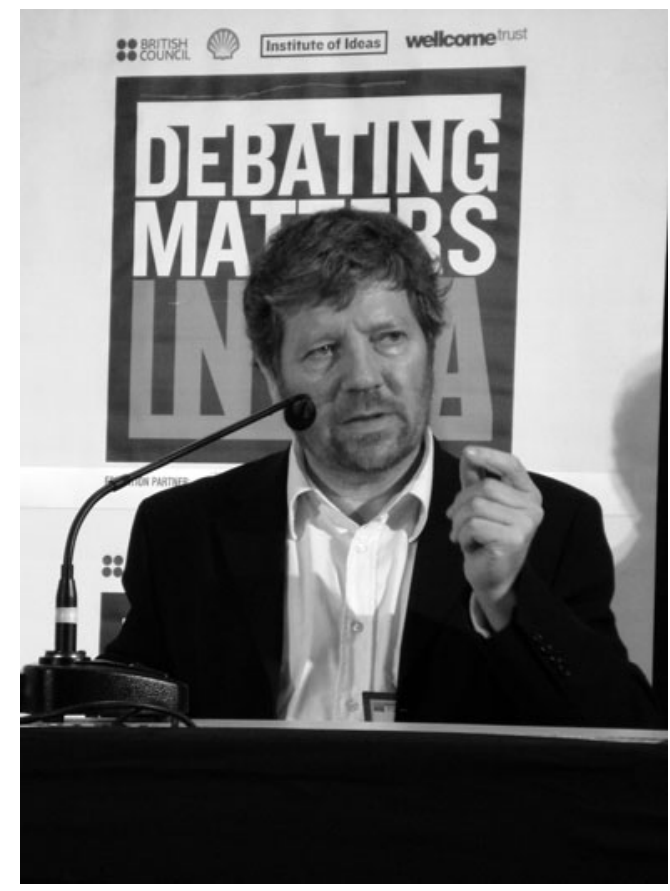

Figure 1. David Graddol argues in Chennai that the importance of English is overstated (Photo: Ilanthenral Kandasamy).

'The importance of learning English in India is overstated'. It was an opportunity for me to talk about some of the negative social and economic consequences of the new enthusiasm for English in India. But I faced a formidable debating rival in the form of Meena Kandasamy, a Tamil writer and poet who is a passionate advocate for English and its potential for liberating the low castes of India from poverty. I had prepared myself to lose the argument miserably against such an adversary, but fortunately no vote was taken - so as not to prejudice the contest between the debating teams which tackled the issues later. However, after questions from the audience, Meena Kandasamy retreated rather shocked at the apparently 'casteist' attitudes of some of the audience, drawn from the elite English-medium schools who seemed less concerned about social justice than how they felt crowded out from jobs and university places by statutory quotas for the 'backward castes'. India may be changing, but English still marks a sensitive social divide. Back in Hong Kong I set my 'World Englishes' students an exam question: 'In Indian development, is English best seen as a part of the problem or as part of the solution?' Hardly a fair question, since I don't know the answer myself.

Closer home, it was the turn of the University of Macau in December to host the latest conference on 'English in South East Asia'. It is the fifteenth such event, which has grown from being a regional event on local Englishes to an international conference on World Englishes held in South East Asia.

Perhaps this is an indicator of how the periphery has become more central in the world of English? As I look forward to 2011 I can see a number of key events relating to English are taking place in and around Hong Kong. In March, the British Council are holding their international education conference, Going Global, at the Convention and Exhibition Centre in Hong Kong (a building which was completed just in time to hold the ceremony for handing sovereignty back to China). International Education is rapidly becoming a synonym for English-medium education and the English segment of the specialised 'language travel' business. In May there is the fourth ELF (English as a Lingua Franca) conference - the first time it has been held outside Europe. And in August, AILA (the International Applied Linguistics Association) is holding its triennial conference in Beijing.

But there has been one significant event, perhaps the event of the decade for anyone interested in the English language, which makes me feel very much stuck at the periphery. This is the exhibition on the history of English Evolving English: One Language, Many Voices at the British Library in London which opened on 12 November and lasts until 3 April.

If Heathrow had not been closed because of ice and snow before Christmas, I would be able to provide you with a first-hand report. As it is, I have to content myself for the moment with reading the enthusiastic reviews which have already appeared in the press and the blogosphere, where the exhibition appears to have met with universal delight.

For Alison Flood in the Guardian, a highlight was Jonathan Swift's Proposal for Correcting, Improving and Ascertaining the English Tongue.

I am immensely grateful to the British Library for bringing my attention to Swift's wonderful early 18th-century Proposal for Correcting, Improving and Ascertaining the English Tongue - part of a new British Library exhibition detailing the history of the English language - in which he lays into versifiers for the travesties they have committed in the name of poetry.

These Gentlemen, although they could not be insensible how much our Language was already overstocked with Monosyllables; yet, to save Time and Pains, introduced that barbarous Custom of abbreviating Words, to fit them to the Measure of their Verses; and this they have frequently done, so very injudiciously, as to form such harsh 


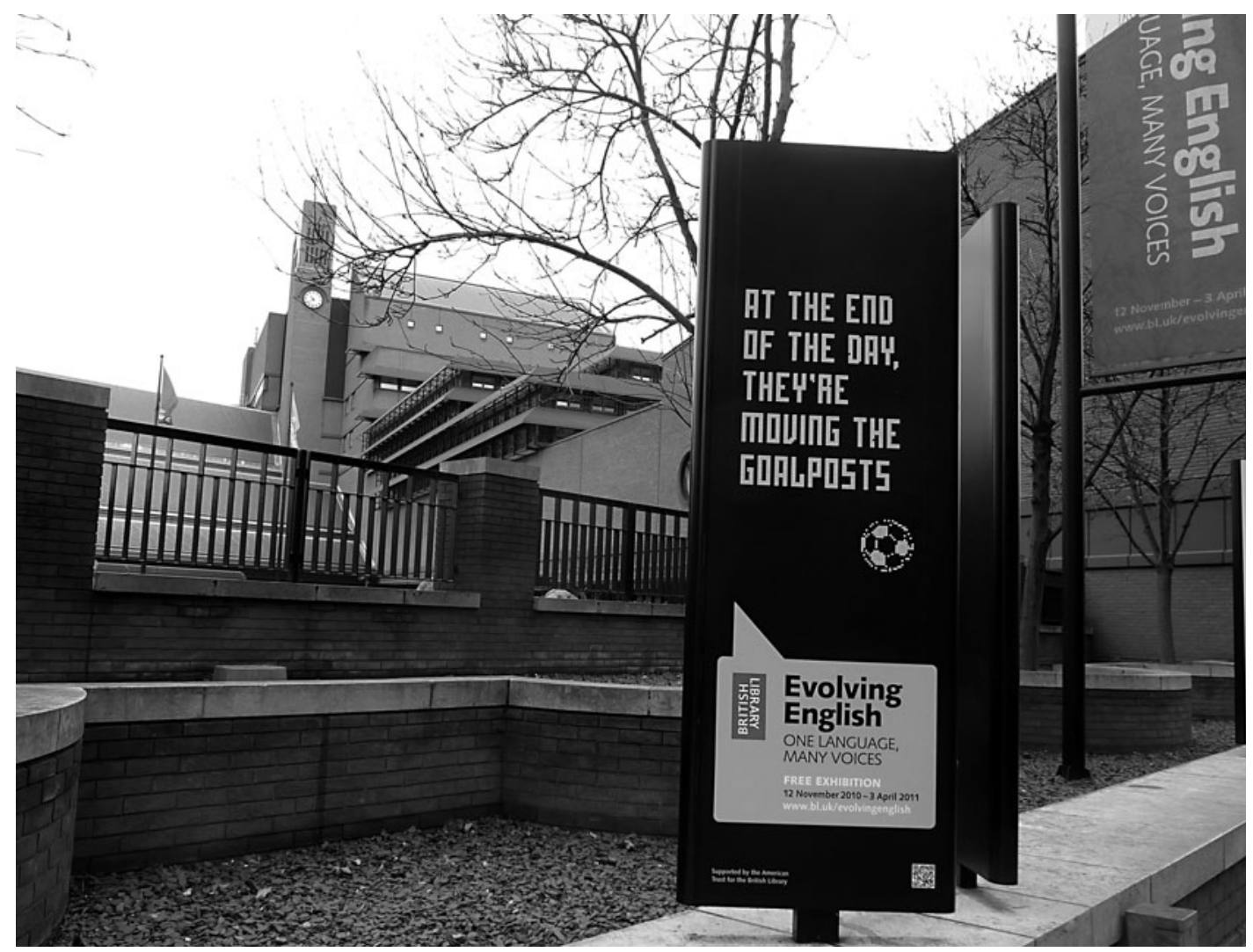

Figure 2. 'Evolving English' at the British Library until April 32011.

unharmonious Sounds, that none but a Northern Ear could endure,

I'm feeling a little silly to realise that, actually, this is nothing new. We've been whining on about the deterioration in English for years and years and years, and perhaps we need to get over ourselves. (http://www.guardian.co.uk/commentisfree/2010/ aug/19/english-language-british-library-books)

The Sun, meanwhile ran the headline Why English is the world's best language. Actually, the article itself was a sober and informative one by Roger Walshe, Head of Learning at the British Library, who tells us:

The exhibition features precious treasures held by the British Library, including a 1,000-year-old manuscript of epic poem Beowulf and Geoffrey Chaucer's racy Canterbury Tales.

(http://www.thesun.co.uk/sol/homepage/features/ 3112106/why-english-is-the-worlds-best-language. $\mathrm{html})$

Michael Rosen, writing for the Socialist Worker, was excited by the history of diversity: it's clear from the moment you walk in that it is about many "Englishes"- the different kinds of English spoken in Britain and all over the world, with the accents and dialects depending on who's speaking and who's listening. . This is an exhibition about change in language located in the moment and place of where and how it happened. It tries to show the struggle over the last four hundred years or so between people who wanted to describe English and those who wanted to control it. (http://www.socialistworker.co.uk/art.php?id=23470)

David Crystal was the 'lead consultant' for the exhibition, and the author of a new book which ties in with the exhibition. He tells us, via his blog,

This is indeed an amazing exhibition, and it was a privilege to be associated with it. It is like having the history of English brought to life. A significant number of the important texts always instanced in histories of the language are in the same room. You are greeted by the glorious Undley bracteate. You find yourself within inches of the Beowulf manuscript. In one cabinet you can see, side by side, the 
Wycliffe Bible, the Tyndale fragment, the Book of Common Prayer, and the King James Bible. The curators have been ingenious, not to say cheeky: in another cabinet you will see the first English conversation, Aelfric's Colloquy; next to it is a manuscript of Harold Pinter. Everywhere you look there are headphones. A visit is not just a visual experience. The Library has an excellent collection of sound recordings, and great efforts have been made to provide an analogous audio experience for the texts of the past. If you are passing through London between now and 3 April 2011, visit this exhibition. There won't be another for a long long time....

There is a great deal of mythology still around - for example, the unfounded belief that linguists say that 'anything goes', when it comes to language teaching in class. Readers of this blog with very long memories will recall that this was something John Humphrys said about me. He eventually apologised, in The Spectator, saying that he was only a journalist, and the role of the journalist was to simplify and exaggerate. But such simplifications and exaggerations do a great deal of harm. So, for the record, once again, and hopefully for the last time: I have never said that 'anything goes' when it comes to language. Read my lips. I have never said that 'anything goes' when it comes to language. Nor do I know of any linguist who has said such a thing. The whole point of sociolinguistics, pragmatics, and the other branches of linguistics which study language in use is actually to show that 'anything does not go'. The only people who use the phrase 'anything goes' are prescriptivists desperately trying to justify their prejudices. (http://david-crystal.blogspot.com/2010/ 12/on-being-champion-of-what.html)

I was struck by the response from writers from unrelated fields. Martin Fenner at PLoSBlogs (a Science and Medicine website) was attracted to the exhibits which document the rise of writing in science, including Robert Hooke's Micrographia - a remarkable treatise on images seen through a microscope, written despite its title - in English.

The technology blog ReadWriteWeb seemed more interested in the facility for visitors to the BL website to record their own voices, and so add to the growing data on pronunciation patterns around the world. (You need to read a section of a Mr Tickle book.)

The British Library says it chose one of the beloved Mr. Men series as the book contained all the lexical sets. (Personally, I preferred Mr. Chatterbox and always found the ending of Mr. Tickle to be quite annoying.) For its part, Mr. Tickle contains words like "mischievous," "postman," and "extraordinary." Do you say "miss-cheevy-us" or "miss-chiv-us"?

The Economist, meanwhile, like the Guardian, was fascinated by the works of some of the 18th century prescriptivists - including Henry Alford and Robert Lowth. The Economist has played a significant role in globalising (note the ' $\mathrm{s}$ ' spelling) British spellings, and its style guide is now used as a global reference. As any regular reader of the Economist knows, it appears compulsory for the anonymous contributors to the magazine to finish their articles with a knowing rhetorical flourish. Their piece on Evolving English was no exception.

Strange then that the exhibition fails to explore the one thing that, above all, gives English its witty flexibility, its gift for pun and double meaning, and that is the absence of accents and grammatical gender. No masculine, feminine, neuter, acute, grave or cedilla for your free-spirited Anglophone. Not only was Shakespeare the greatest English writer, he could have been no other kind.

I'm still musing on that one. 